МРНТИ 29.19.22

УДК 546.26

https://doi.org/10.51889/2020-2.1728-7901.29

\title{
PRODUCTION OF NANOMATERIALS FOR APPLICATION AS ADDITIVES
}

\author{
Ospanbekov E.A. ${ }^{1}$, Paritzan G. ${ }^{2}$ Ismailov D.V. ${ }^{2}$, Kerimbekov D.S. ${ }^{2}$ \\ ${ }^{1}$ Abai Kazakh National pedagogical University, Almaty, Kazakhstan, \\ ${ }^{2}$ al-Farabi Kazakh National University, Almaty, Kazakhstan
}

\begin{abstract}
This paper presents the results of the obtained carbon nanostructures by the method of arc synthesis in helium. During the synthesis, the methodology for producing fullerene-containing soot was worked out and the yield of fullerenes was increased by $6 \%$ at an optimal current of $180 \mathrm{~A}$ and a voltage of $30 \mathrm{~V}$, at a vacuum in the reactor of 0.004 Torr, and helium supply of $0.4 \mathrm{~kg} / \mathrm{cm}^{2}$, water temperature of the cooling system $\sim 19^{\circ} \mathrm{C}$, The obtained nanostructures were subjected to purification by evaporation using a Soxhlet apparatus in 5 cycles. Then the obtained fullerenes $\mathrm{C}_{60}$ and $\mathrm{C}_{70}$ were investigated using analytical instruments confirming their presence. After that, the obtained fullerene mixtures were prepared in suspension and tested on a friction and wear machine.During the experiments, the optimal proportions of mixtures of fullerenes with industrial oils I - 40, as well as additives of metal micropowders were selected. The results of the analysis showed that the addition of fillers reduced friction and wear by $3-4 \%$, which improves the effectiveness of additives from previous studies.
\end{abstract}

Keywords: Carbon nanostructures, fullerenes, Raman spectroscopy, optical microscopy, arc synthesis, oils, additives.

\author{
Аннотациия \\ Е.А. Оспанбеков ${ }^{1}$, Г. Паритзан ${ }^{2}$, Д.В. Исмаилов ${ }^{2}$, Д.С. Керимбеков ${ }^{2}$ \\ ${ }^{1}$ Казахский Национальный педагогический университет имени Абая, Алматы, Казахстан \\ ${ }^{2}$ Казахский Национальный университет им. аль-Фараби, Алматы, Казахстан \\ ПРОИЗВОДСТВО НАНОМАТЕРИАЛОВ ДЛЯ ПРИМЕНЕНИЯ В КАЧЕСТВЕ ДОБАВОК
}

В работе представлены результаты полученных углеродных наноструктур методом дугового синтеза в среде гелия. В процессе синтеза была отработана методика получения фуллереносодержащей сажи и увеличен выход фуллеренов на 6\% при оптимальном токе 180 А и напряжении 30B, при вакууме в реакторе $\sim 0,004$ Torr, и

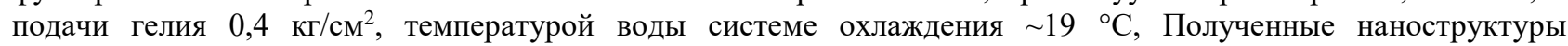
подвергались отчистке методом выпаривания с помощью аппарата Сокслета в 5 циклов. Затем полученные фуллерены $\mathrm{C}_{60}$ и $\mathrm{C}_{70}$ исследованы с помощью аналитических приборов, подтверждающих их наличие. После чего полученные смеси фуллеренов были приготовлены в суспензии и протестированы на машине трения и износ. В ходе проведения эксперементов были подобраны оптимальные пропорции смесей фуллеренов с индустриалальными маслами И - 40, а таже добавками металлических микропорошков. Результаты анализа показали, что добавка наполнителей уменьшило трение и износ на 3-4\%, что улучшает эффективность присадок из предыдущих исследований.

Ключевые слова: Углеродные наноструктуры, фуллерены, спектроскопия комбинационного рассеяния, оптическая микроскопия, дуговой синтез, масла, присадки.

\section{Аңдатпа \\ Е.А. Оспанбеков ${ }^{1}$, Г. Паритзан ${ }^{3}$, Д.В. Исмаилов ${ }^{4}$, Д.С. Керимбеков ${ }^{5}$ \\ ${ }^{1}$ Абай атындавы Қазақ ұлттық педагогикалық университеті, Алматы, Қазақстан \\ 2 әл-Фарабиатындавы Қазақ ұлттық университеті, Алматы, Қазақсттан \\ ҚОСПАЛАР РЕТІНДЕ ҚОЛДАНУҒА АРНАЛҒАН НАНОМАТЕРИАЛДАР ӨНДІРІСІ}

Бұл жұмыста гелийде доғалық синтез әдісімен алынған көміртекті наноқұрылымдардың нәтижелері келтірілген. Синтездеу кезінде фуллереннен тұратын күйе алу әдісі жасалды және оңтайлы ток кезінде 180 А және кернеуі 30 В, вакуумда 0,004 Тор, ал гелиймен қамтамасыз ету 0,4 кг / см², салқындату жүйесінің су температурасы $\sim 19^{\circ} \mathrm{C}$, фуллереннің кірістілігі 6\% -ға артты. С, Алынған наноқұрылымдар 5 циклде Сокслет аппаратын пайдаланып булану арқылы тазартуға ұшырады. Содан кейін алынған С 60 және С 70 толық өлшемдері олардың болуын растайтын аналитикалық құралдардың көмегімен зерттелді. Осыдан кейін алынған фуллерен қоспалары суспензияда дайындалып, үйкеліс және тозу машинасында сыналды.Тәжірибелер барысында фуллерендердің И - 40 өнеркәсіптік майларымен, сондай-ақ металл микропроцестердің қоспаларымен оңтайлы 
қатынасы тандалды. Талдау нәтижелері көрсеткендей, толтырғыштарды қосу үйкеліс пен тозуды 3-4\% төмендетеді, бұл алдыңғы зерттеулердегі қоспалардың тиімділігін арттырады.

Түйін сөздер: көміртекті наноқұрылымдар, фуллерендер, комбинациялық шашыраудың спектроскопиясы, оптикалық микроскопия, доғалы синтезі, май, қоспалар.

\section{Introduction}

In 1990, after the moment when it was found out the way of production of fullerenes in gram quantities, the new research began for their practical application. Large-scale studies on the use of fullerenes in many fields of science, technology and production are still in the progress. The standing point on their use is the high cost of fullerenes. However, the search for less price solutions does not stop even nowadays. Many books have already been published [1-5], which describe the methods of preparation, structure and properties of fullerene-containing materials, indicate the directions of their application and describe the advantages of new materials.

Fullerenes can be used to improve the operational characteristics of mechanisms (vehicles, etc.). Thus additives to oils and lubricants increase the wear resistance of friction pairs, anti-seize compounds are used for units operating under the high loads, brake pad composites are used for high-speed vehicles. Modified by fullerenes, wood composites are used in stern and similar bearings, and lubricating-cooling technological compounds are used for the operation of tools.

Based on the general relevance of the research topic in the world today, the decision was made to conduct a series of experiments to obtain additives based on carbon nanostructures - fullerenes within the framework of existing equipment at the National Nanotechnology Laboratory (NNLOT) at KazNU named after alFarabi. In this work, additives based on the fullerenes were obtained. The analysis of the study was carried out with the use of Raman spectroscopy and optical microscopy, as well as the testing installation for defining friction by the Timken method in the laboratory.

During our research work, we, first of all, have obtained carbon nanostructures in an arc synthesis unit in an inert helium medium shown in Figure 1 (on the left). At the beginning, to start working on the installation, it was necessary to anneal graphite rods in a vacuum furnace at a temperature of $600{ }^{\circ} \mathrm{C}$ for 3 hours, Figure 1 (at the center).

An MPG-7 brand graphite electrode was used in the experiment. After that, the annealed rods were previously weighed and then placed in the reactor of the installation. Next, the reactor was vacuumed, and following that an inert helium gas was gradually injected, and graphite rods were gradually joint at a small voltage of $\sim 30 \mathrm{~V}$ and a current of $\sim 200 \mathrm{~A}$. During the closure of the lower anode rod, a spark (arc) was formed with a temperature of $\sim 700{ }^{0} \mathrm{~K}$ in the center of the arc, thereby burning the lower anode graphite rod. After synthesis, carbon-containing soot appeared on the walls of the reactor, fig. 1 (on the right), which was then poured into a container and weighed on an analytical balance. The loss of mass of graphite during the synthesis was about $10-20 \%$.
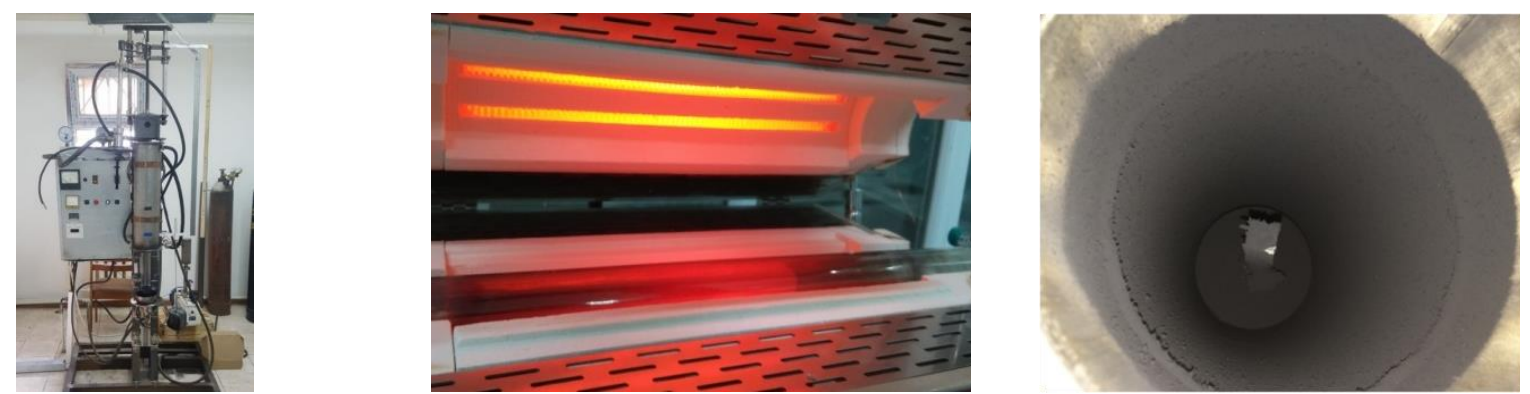

Figure 1. General view of the installation

Subsequently, the obtained carbon nanostructured carbon soot was collected from the installation and passed through a fine sieve with a mesh size of $500 \mu \mathrm{m}$ for uniform distribution of fullerenes throughout the volume of carbon soot. Also, during the synthesis, a "deposit", shown in Figure 2, was obtained from the upper burnt cathode graphite rod, which may vary depending on the pressure of the buffer gas in the reaction zone. In such an experiment, one can obtain amorphous carbon, single-walled nanotubes (SWNTs), and multi-walled nanotubes (MWNTs). 


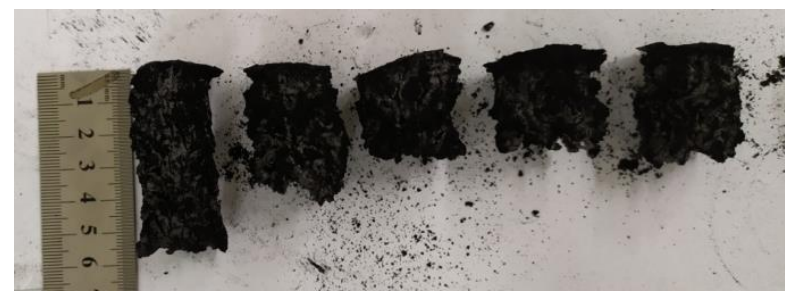

Figure 2. Carbon deposit, consisting of amorphous carbon, SWNTs and MWNTs.

By changing the experimental conditions and the characteristics of the production of carbon nanomaterials, it is possible to increase the volume of soot and reduce the "deposit". The main component of the "deposit" is amorphous carbon. Amorphous carbon is the smallest crystals that are not arranged uniformly, but randomly. During our experiments, there were worked out the modes, where, as the result, the carbon "deposit" accounts for only $15-20 \%$ of the total mass of the graphite electrode.

Then, after weighing, carbon soot was packaged in the filter paper, which passed through 5 cleaning cycles on a Soxhlet apparatus. The Soxhlet apparatus is used to evaporate at a low temperature and isolate fullerite crystals, thereby isolating a mixture of fullerenes from carbon soot. Figure 3 shows how the Soxhlet apparatus is used to evaporate fullerenes in help of toluene vapor condensed by a cyclic ring stream.

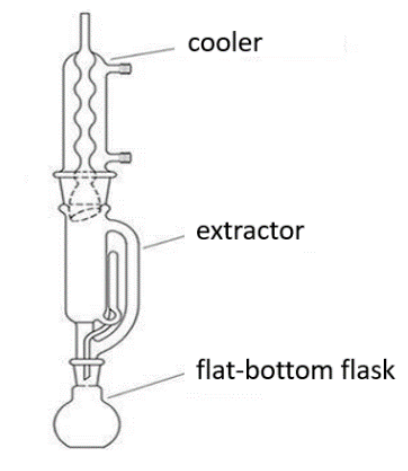

Soxhlet installation scheme

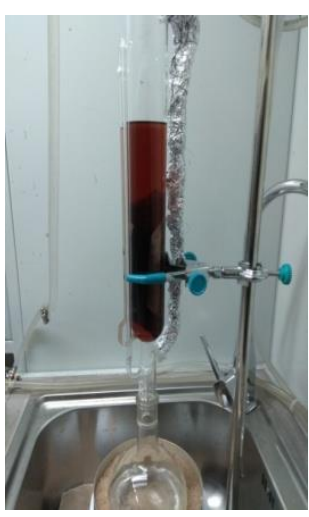

Cycle 1

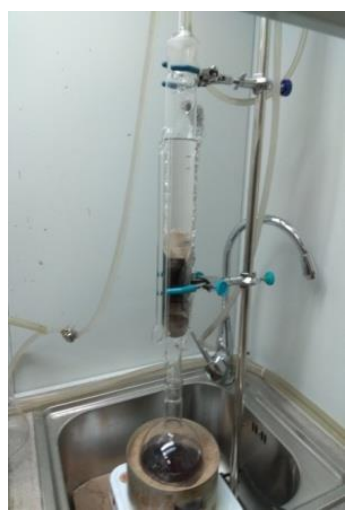

Cycle 2

Figure 3. Isolation of fullerenes from fullerene-containing soot

The isolated fullerenes from soot were evaporated, thereby forming solid crystals called fullerites (See figure 4).Figure 4 shows optical microphotographs of fullerite crystals obtained by us under the condition of different electric current, where we can see the change in the geometric shape of fullerite as a function of the current change supplied to graphite electrodes, with the use of a direct current source, which was served as a welding rectifier.

The synthesis was carried out several times, during which the installation mode for producing carbon nanostructures was developed, thereby increasing the output of the fullerene mixture from $4 \%$ to $6 \%$ by choosing the optimal temperature and pressure, as well as other small parameters.Also, the obtained fullerene-containing soot was used by us as an additive, by preparing a suspension from the industrial oil I 40A. The produced suspension was stirred with a magnetic stirrer during several hours. Then a friction machine was involved into the work, which made it possible to check quickly the quality of lubricants for holding the oil film in the steel-steel friction pairs under various loads. Temkin's machine imitated the operation of a node of working mechanisms, where lubricants played an important role in the speed of wear of parts of these nodes.

Figure 5 shows the Raman spectrum, from which the presence of the obtained $\mathrm{C}_{70}$ crystals can be seen. The position of the peaks in the spectrum of the studied crystals - fullerites - corresponds to the peaks of sample $\mathrm{C}_{70}$ presented at the reference $[6,7]$.

Figure 5 shows the Raman spectrum, which was captured using the integrated complex of probe and optical microscopy and spectroscopy, AFM - Raman - SBOM - TERS. From the Raman spectrum, it is seen that C70 fullerenes are present. Figure 6 shows the installation for checking friction material wear (steelsteel). 
At the initial moment of friction, the upper layers of the friction pair were dispersed with the formation of fine particles of material.
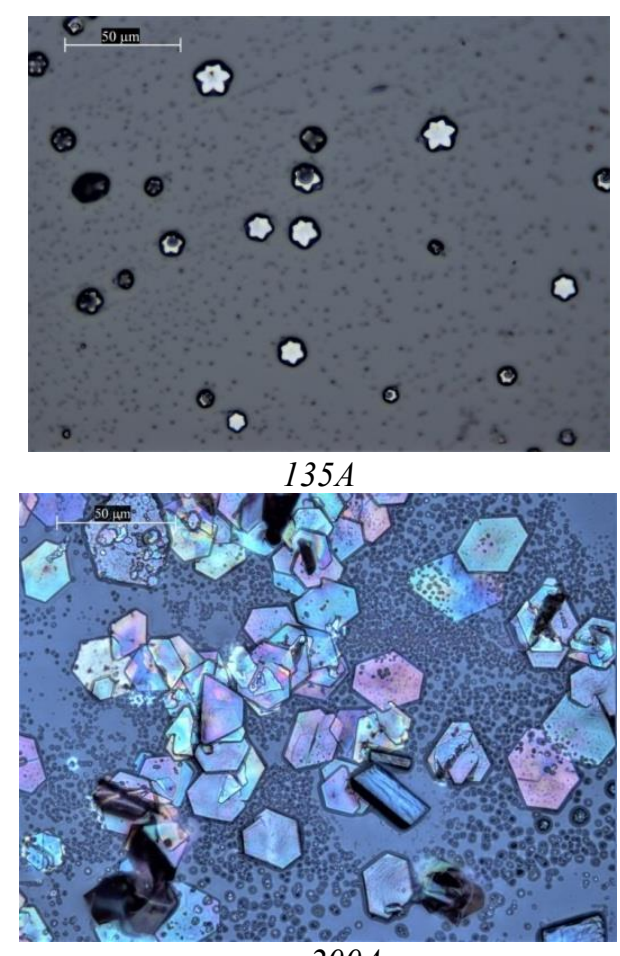

$200 \mathrm{~A}$

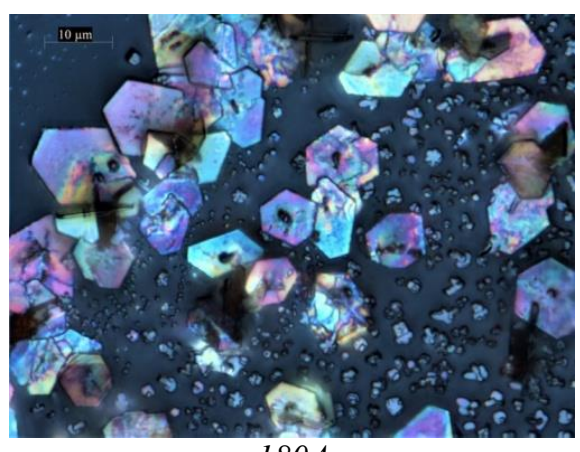

$180 \mathrm{~A}$

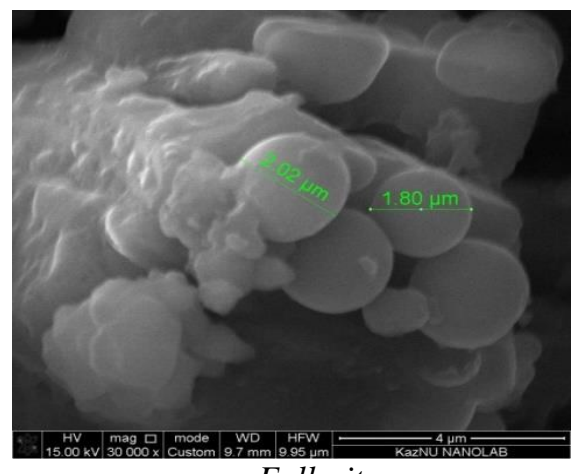

Fullerite

Figure 4. Microphotographs of the obtained fullerites obtained by the increasing of electric current.

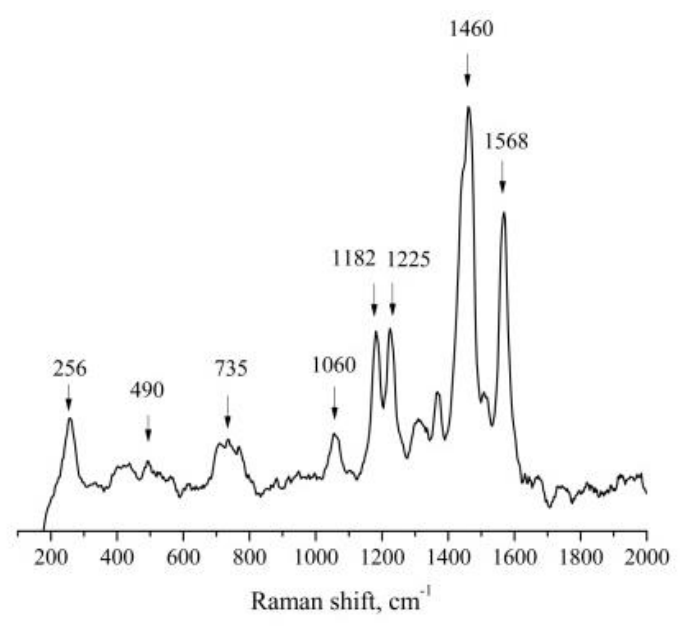

Figure 5. Spectra of fullerenes $C_{70}$ 


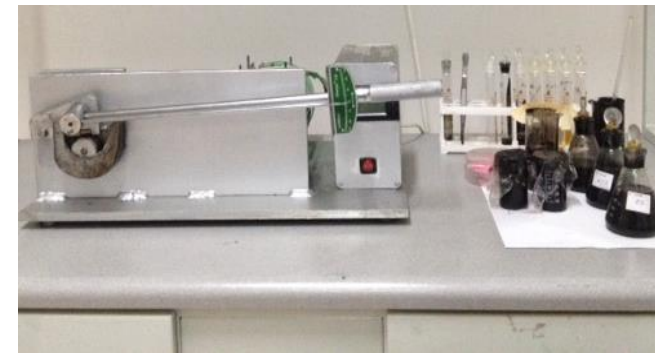

a

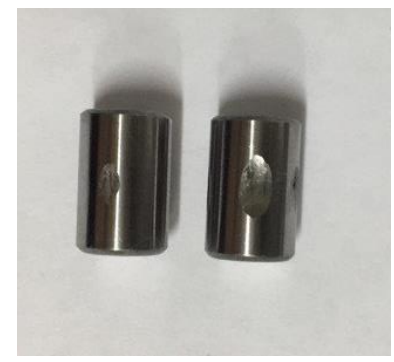

$\mathrm{b}$

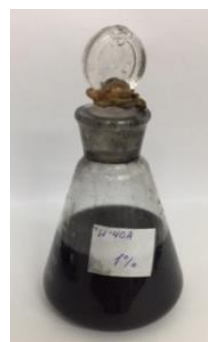

$\mathrm{c}$

Figure 6. a) a Timken machine for checking the reduction of friction, b) an erased bearing with an additive from a fullerene-containing suspension, on the right without an additive at erased bearing. $c$ ) a suspension of fullerenecontaining soot.

Interacting with the environment and with the active elements, the surface defects of the working element were filled in. Subsequently, with the steady state of the contacting surface, a thin film of material was coated, which sharply increased the actual contact area (more than 10 times).

This contributed to an increase in the durability of friction units. The resulting lubricants made it possible to increase the efficiency by $1 \%$, leading to an increase of engine power up to $\sim 4 \%$, since $25 \%$ of the efficiency corresponds to the full power of the engine. Reducing losses in this of steel - steel pair contributed not only to an increase in power of engine, but also brought to significant fuel economy.

\section{Conclusion}

In the course of conducting and testing the production of carbon nanomaterials, the output of fullerenes was effectively increased from $4 \%$ to $6 \%$ at the facility by varying the modes of graphite rod burning rate and pressure up to $30.7 \mathrm{kPa}$, as well as other small parameters at the facility.

The obtained fullerene materials were used as a lubricant, which allowed to reduce the friction and bearing wear on an average rate of $3-4 \%$. This effect was most likely due to the fact that, in the process of tribopolymerization of mineral oil on rubbing surfaces, there was formed a coating in the form of a spatial tribopolymer network connected to the substrate. This coating protected the rubbing surfaces, threw steelsteel from direct contact, preventing mass transfer between the rubbing contacts and, at the same time, being a spatial polymer network, retained mineral oil in its cells, thus providing both a low-wear friction regime and a low friction coefficient. A further detailing of the supramolecular structure of the surface film requires additional research.

\section{References:}

1 Shinar J. (2000). (ed.) Optical and electronic properties of fullerenes and fullerene-based materials. New York: Marcel Dekker, Inc. 380.

2 Gusev A.I., Nanocrystalline materials Gusev A.I., Rempel A.A. M Fizmatlit. 2001.224.

3 Shpak A.P., (2001) Cluster and nanostructured materials Shpak A.P., Kunitsky Yu.A., Karbovsky V.L. Kiev: "Academic Period.". 587.

4 Matysina Z.A., Hydrogen and solid-phase transformations in metals, alloys and fullerites Matysina Z.A., Schur D.V. Dnepropetrovsk: Science and education. 2002420.

5 Veziroglu T.N., Hydrogen materials science and chemistry of carbon nanomaterials Veziroglu T.N., Zaginaichenko S.Yu., Schur D.V., Baranowski B., Shpak A.P., Skorokhod V.V. (2004) (eds.) Dordrecht-Boston-London: Kluwer Academic Publishers. 660.

6 Brett Kimbrell J. (2014). et. al. Analysis of mixtures of $C_{60}$ and $C_{70}$ by Raman spectrometry Nanoscience Methods. 3 (1). 40-46.

7 Talyzin A.V. (2001) New Fullerene Materials Obtained in Solution and by High Pressure High Temperature Treatment Acta Universitatis Upsaliensis. Comprehensive Summaries of Uppsala Dissertations from the Faculty of Science and Technology 663.54. 